\title{
PENGARUH SUMBER AIR PENYIRAMAN DAN FREKUENSI PENYEMPROTAN INSEKTISIDA TERHADAP PERTUMBUHAN DAN KANDUNGAN TIMBAL (Pb) PADA TANAMAN SELADA
}

\author{
Etik Puji Handayani, Rakhmiati, Yatmin'1) \\ 1)Jurusan Agroteknologi, Sekolah Tinggi Pertanian Dharma Wacana Metro, Jl. Kenanga No. 3 Mulyojati $16 \mathrm{C}$ \\ Metro, Kota Metro. Email: etik_ph@yahoo.com. Hp. 081574004775
}

\begin{abstract}
Water management and technology of protection insectiside could be changes availability heavy metal in soil and plant. The objective of this research was to study the effect of water source to spray vegetables and frequency sprayer insecticide on the growth and $\mathrm{Pb}$ contain in vegetable. The experimental design was factorial in randomized completely block design with three replications. The result showed the effect of water source to spray vegetables and frequency insecticide spray not significant on the growth vegetables, but significant on Pb contain in vegetables. The maximum Pb (7,97 ppm) in sludge from household and twice insecticide spray.
\end{abstract}

Keywords: Water source, frequency insecticide, Heavy metal Pb, vegetable.

\section{PENDAHULUAN}

Komposisi kimia air pengairan beragam sesuai dengan reaksi-reaksi yang terjadi dalam sistem batuan-tanah-airudara menurut keadaan geologi dan iklim. Air pengairan memang dapat menyumbangkan beberapa macam unsur hara yang dibutuhkan untuk pertumbuhan sayuran, namun jika air yang digunakan untuk mengairi lahan sayuran berupa limbah cair yang berasal dari kegiatan pemukiman, pertambangan, atau industri, seperti yang terjadi pada lahan sayuran di daerah perkotaan maka dapat menimbulkan masalah karena limbah tersebut pada umumnya mengandung berbagai macam unsur logam berat termasuk Timbal $(\mathrm{Pb})$ yang bersifat toksis bagi manusia.

Para petani sayuran dalam setiap kegiatan budidayanya selalu akan berhadapan dengan berbagai hama tanaman yang kemampuan berkembangnya sangat dipengaruhi oleh lingkungan pertanaman tanamannya. Serangan hama utama tanaman sayuran kol daun, kol bunga, petsay, sawi, selada, dan lobak, seperti Plutella maculipennis dan Crocidolomi binotalis dapat berlangsung sepanjang waktu pertumbuhan tanaman, sehingga petani tidak akan terlepas dengan insektisida dalam membasmi hama tersebut. Tindakan preventif yang sering dilakukan oleh petani adalah penyemprotan insektisida pada tanamantanaman muda yang masih berada dalam persemaian. Selanjutnya dilakukan penyemprotan lagi seminggu setelah tanaman dipindahkan ke lapangan. Bila tanaman mulai diserang dilakukan tindakan kuratif berupa penyemprotan intensif dua sampai tiga kali. Cara budidaya yang demikian dapat membahayakan kesehatan manusia karena semakin sering dilakukan penyemprotan, maka bahan aktif dari insektisida yang terabsorpsi sayuran semakin tinggi.

Menurut Herawati et al. (1998), tingkat toksisitas logam berat dalam tanaman sangat dipengaruhi oleh kondisi tanah dan lingkungannya. Selanjutnya Soepartini dkk. (1996) melaporkan bahwa pengelolaan air dan teknik pengendalian hama dapat menyebabkan perubahan keberadaan logam berat pada tanah tersebut, sehingga secara nyata dapat mempengaruhi kandungan logam berat dalam tanaman. Laporan Alegria et al. (1991) menunjukkan kandungan $\mathrm{Pb}$ dalam sayuran lebih dipengaruhi oleh antropogenik dan faktor lingkungan. Hasil analisis air, tanah dan tanaman yang diambil dari beberapa kebun sayuran caisin dengan perbedaan sumber air penyiraman menunjukkan bahwa sumber air irigasi yang bersih sangat menentukan kandungan $\mathrm{Pb}$ dalam air dan berkorelasi positif dengan nilai $\mathrm{pH}$ tanah. Dengan nilai $\mathrm{pH}$ tanah yang rendah ternyata status logam $\mathrm{Pb}$ dalam sayuran caisin lebih tinggi (Handayani et al., 2005).

Air yang digunakan mengairi kebun sayuran mempunyai komposisi kimia yang beragam, bergantung pada bahan-bahan yang ikut terlarut dan terangkut selama perjalanannya, apakah mengandung logam berat yang bersifat toksis bagi kehidupan manusia seperti $\mathrm{Pb}$ atau tidak, sampai akhirnya air bersama bahan terlarut akan terinfiltrasi ke dalam lapisan tanah yang lebih dalam atau langsung diabsorpsi oleh akar tanaman. Dengan demikian sumber air yang digunakan untuk pertumbuhan tanaman sangat menentukan kandungan logam berat dalam tanaman.

Timbal yang telah terabsorbsi tersebut akan terakumulasi dalam organ-organ tanaman seperti akar, batang, dan daun yang akhirnya kita konsumsi, sedangkan yang terinfiltrasi akan menambah kandungan $\mathrm{Pb}$ dalam tanah yang nantinya juga dapat terabsorbsi oleh akar tanaman. Pengaruh sumber air penyiraman terhadap pertumbuhan tanaman selada mungkin menunjukkan perbedaan jika sumber airnya berbeda. Hal ini terkait dengan terikutnya bahan-bahan terlarut dalam air tersebut. Banyaknya bahan-bahan terlarut yang diabsorpsi oleh tanaman dan diakumulasikannya bahan-bahan tersebut dalam organ tanaman akan berpengaruh terhadap kandungan $\mathrm{Pb}$ dalam daun selada. Handayani et al., (2005) telah melakukan kajian awal tentang kandungan logam berat dalam sayuran dari lokasi sentral kebun sayuran di Kota Metro yang kualitas air pengairannya masih tergolong 
bersih dan dua sentral kebun sayuran di Bandar Lampung yang kualitas air pengairannya tergolong lebih kotor dengan lokasi kebun sayuran yang berbeda (dekat dengan jalan raya dan jauh dari jalan raya). Hasil yang diperoleh menunjukkan bahwa kandungan $\mathrm{Pb}$ dan $\mathrm{Hg}$ dalam air di Kota Metro lebih rendah daripada yang terukur di Bandar Lampung (Tabel 1).

Tabel 1. Kandungan Pb Dalam Air pada Beberapa Kebun Sayuran dengan Kualitas Air yang Berbeda

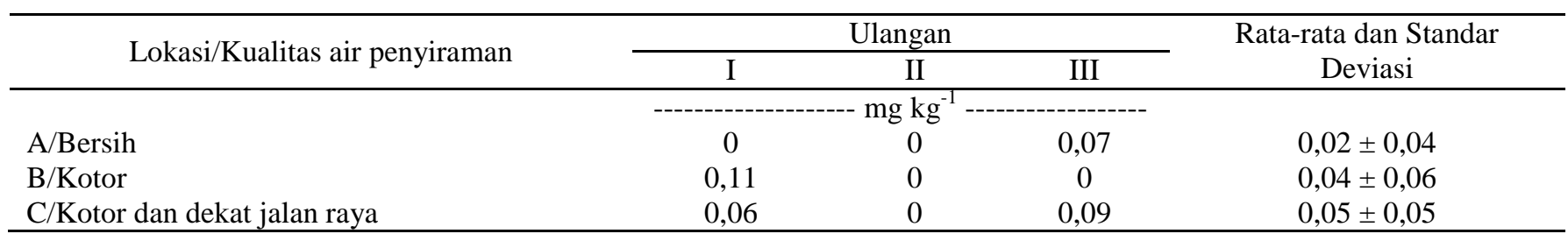

Keterangan :

A = Kebun sayuran Karang Rejo Kota Metro

$\mathrm{B}=$ Kebun sayuran Way Dadi Bandar Lampung

$\mathrm{C}=$ Kebun sayuran Way Halim Bandar Lampung

Timbal merupakan salah satu bahan penyebab polusi utama logam berat (Salam et al., 1997). Menurut Yeh et al. (1996), beberapa insektisida banyak ditemukan unsur $\mathrm{Pb}$. Penyemprotan insektisida pada sayuran dapat mencegah munculnya hama dan secara langsung membasmi hama yang menyerang tanaman sehingga pertumbuhan sayuran baik dan hasilnya tinggi, namun penyemprotan insektisida akan menghasilkan residu bahan aktif pada sayuran yang kita konsumsi. Semakin sering penyemprotan insektisida, maka semakin banyak akumulasi residunya, sehingga semakin tinggi efek residu tersebut untuk kesehatan manusia.

Sumber air penyiraman mempengaruhi kualitas air sebagai pelarut yang sangat vital untuk kehidupan tanaman selada. Demikian juga pencegahan dan pemberantasan hama tanaman sangat diperlukan untuk mempertahankan hasil tanaman. Pengaruh kedua faktor ini akan saling berinteraksi dalam pertumbuhan dan kandungan $\mathrm{Pb}$ pada daun tanaman selada.

Menurut Moir dan Thornton (1998), kandungan $\mathrm{Pb}$ dalam sayuran berkisar antara 0,25-16,7 $\mu \mathrm{g} \mathrm{g}^{-1}$ berat kering dan kandungan $\mathrm{Cd}$ dalam sayuran berkisar antara 0,025$10,4 \mu \mathrm{g} \mathrm{g}^{-1}$ berat kering. Sehingga dapat dihitung jika kita mengkonsumsi $100 \mathrm{~g}$ sayuran dalam sekali makan, berarti kita telah menyerap 0,25-16,7 $\mu \mathrm{g}$ logam $\mathrm{Pb}$ (asumsi $100 \mathrm{~g}$ berat basah setara dengan $1 \mathrm{~g}$ berat kering). Kebiasaan kita makan sehari tiga kali, berarti dalam sehari kandungan logam $\mathrm{Pb}$ yang terakumulasi antara $0,75-50,1 \mu \mathrm{g}$. Sayuran dikonsumsi setiap hari dengan tujuan hidup sehat, namun apakah tujuan itu tercapai jika yang kita makan itu mengandung logam berat yang bisa menjadi berbahaya karena sistem bioakumulasinya. Dengan demikian perlu dikaji lebih lanjut efek kebiasaan petani sayuran yang menyiram tanaman dengan air limbah dan penyemprotan insektisida berlebih akibatnya terhadap pertumbuhan dan kandungan $\mathrm{Pb}$ dalam tanaman sayuran.

Penelitian sumber air pengairan dan penyemprotan insektisida dalam kaitannya dengan kandungan $\mathrm{Pb}$ yang diabsorbsi dan terakumulasi dalam sayuran sangat perlu dilakukan karena konsumsi sayuran tidak bisa dipisahkan dari kehidupan manusia. Jika logam $\mathrm{Pb}$ masuk ke dalam tubuh bersama sayuran yang kita makan, maka $\mathrm{Pb}$ cenderung terakumulasi di dalam tubuh, masuk ke peredaran darah dan sel saraf menggantikan kalsium dan sukar diekskresikan.

Penelitian ini bertujuan untuk mengetahui:

(1) Pengaruh sumber air penyiraman terhadap pertumbuhan dan kandungan $\mathrm{Pb}$ dalam tanaman selada.

(2) Pengaruh frekuensi penyemprotan insektisida terhadap pertumbuhan dan kandungan $\mathrm{Pb}$ dalam tanaman selada.

(3) Interaksi antara sumber air penyiraman dan penyemprotan insektisida terhadap pertumbuhan dan kandungan $\mathrm{Pb}$ dalam tanaman selada.

Hipotesis yang diajukan dalam penelitian ini adalah :

(1) Sumber air penyiraman yang berbeda memberikan pengaruh yang berbeda terhadap pertumbuhan dan kandungan $\mathrm{Pb}$ dalam tanaman selada.

(2) Semakin sering penyemprotan insektisida semakin bagus pertumbuhan tanaman, namun kandungan $\mathrm{Pb}$ dalam tanaman selada semakin tinggi.

(3) terdapat interaksi antara sumber air penyiraman dan penyemprotan insektisida terhadap pertumbuhan dan kandungan $\mathrm{Pb}$ dalam tanaman selada.

\section{BAHAN DAN METODE}

Penelitian ini dilaksanakan di Desa Tulusrejo, Kecamatan Pekalongan, Kabupaten Lampung Timur pada bulan Juli - September 2007.

Bahan-bahan yang digunakan dalam penelitian ini adalah: bibit selada, polybag, air sumur, air selokan limbah rumah tangga, insektisida Calypso 240 SC (Thiacloprid 240 $\mathrm{g} / \mathrm{l}$ ), Gandasil D, aquades, tanah top soil, pupuk kandang kambing. Sedangkan alat-alat yang digunakan adalah: alat penyemprot, alat pemotong (gunting dan pisau), ember, gembor, cangkul, meteran, timbangan, oven dan perlengkapan alat-alat tulis.

Metode percobaan disusun secara faktorial dalam Rancangan Acak Kelompok Lengkap (RAKL) dengan 3 ulangan. Faktor pertama adalah sumber air penyiraman (K) terdiri dari 2 taraf yaitu air sumur $\left(\mathrm{k}_{1}\right)$ dan air selokan limbah rumah tangga $\left(\mathrm{k}_{2}\right)$, dan faktor kedua adalah frekwensi penyemprotan insektisida setelah tanam (I) 
terdiri dari 3 taraf yaitu tanpa insektisida $\left(\mathrm{i}_{0}\right), 1$ kali penyemprotan $\left(i_{1}\right), 2$ kali penyemprotan $\left(i_{2}\right)$, dan 3 kali penyemprotan $\left(i_{3}\right)$. Sehingga diperoleh delapan kombinasi perlakuan yaitu: $\mathrm{k}_{1} \mathrm{i}_{0}, \mathrm{k}_{1} \mathrm{i}_{1}, \mathrm{k}_{1} \mathrm{i}_{2}, \mathrm{k}_{1} \mathrm{i}_{3}, \mathrm{k}_{2} \mathrm{i}_{0}, \mathrm{k}_{2} \mathrm{i}_{1}, \mathrm{k}_{2} \mathrm{i}_{2}$, dan $\mathrm{k}_{2}$ $\mathrm{i}_{3}$.

Data yang diperoleh dianalisis ragam dengan membandingkan F-hitung dengan F-tabel pada taraf 5\% dan dilanjutkan dengan uji beda nyata terkecil (BNT) pada taraf $5 \%$, tetapi sebelumnya dilakukan uji kehomogenan ragam perlakuan dengan uji Bartlett dan ketak-aditifan data dengan uji Tuckey.

Pelaksanaan Penelitian diawali dengan penyiapan media tanam. Media tanam yang digunakan adalah top soil yang telah dikering udarakan dan diayak, kemudian dicampur dengan pupuk kandang kambing dengan perbandingan volume $2: 1$. Campuran tanah dan pupuk kandang kambing sebanyak $2 \mathrm{~kg}$ dimasukkan ke dalam polybag. Media tanam disiram dengan air sampai dengan kapasitas lapang dan dibiarkan selama satu minggu. Bibit selada dari tempat persemaian dipilih yang besarnya seragam, kemudian di tanam pada polybag yang telah dipersiapkan sebelumnya. Bibit ditanam satu buah per polybag. Pupuk dasar tidak diberikan, namun tanaman disemprot pupuk daun Gandasil D dengan konsentrasi $3 \mathrm{~g} \mathrm{l}^{-}$ 1 untuk menjaga pertumbuhannya pada saat tanaman berumur 10 dan 17 hari setelah tanam (hst).

Pemberian Perlakuan dilakukan dengan berpedoman kepada metode penelitian. Perlakuan pertama berupa penyiraman; tanaman selada disiram dengan air sumur dan air limbah rumah tangga dengan volume $150 \mathrm{ml}$. Penyiraman dilakukan dengan memperhatikan kondisi media tanam, tidak dilakukan penyiraman jika media tanam masih terlalu basah. Perlakuan kedua berupa penyemprotan insektisida Calipso 240 SC. Penyemprotan insektisida dilakukan sesuai dengan perlakuan yaitu untuk yang satu kali penyemprotan, penyemprotan dilakukan pada saat tanaman berumur 24 hst; untuk yang dua kali penyemprotan, penyemprotan dilakukan pada saat tanaman berumur 16 dan 24 hst; dan untuk yang tiga kali penyemprotan, penyemprotan dilakukan pada saat tanaman berumur 8, 16, dan 24 hst; sedangkan untuk perlakuan tanpa insektisida, tanaman disemprot dengan air bersih dari sumur. Volume semprot untuk satu kali penyemprotan adalah $2 \mathrm{ml}$ dengan konsentrasi $2 \mathrm{ml} \mathrm{l}^{-1}$.

Variabel yang diamati dalam penelitian ini adalah: (1) tinggi tanaman, dilakukan dengan cara mengukur tinggi tanaman dari permukaan tanah hingga titik tumbuh tanaman selada pada saat umur tanaman 25 hst, dengan satuan centi meter, (2) Jumlah daun, dilakukan dengan cara menghitung jumlah daun yang tumbuh pada saat umur tanaman $25 \mathrm{hst}$, dengan satuan buah, (3) berat basah berangkasan, dilakukan dengan cara menimbang berat per tanaman pada saat umur tanaman 25 hst, dengan satuan gram, (4) berat kering berangkasan, dilakukan dengan cara pengeringan sampel tanaman dalam oven pada suhu $70{ }^{\circ} \mathrm{C}$ sampai bobotnya konstan, sampel tanaman diambil pada saat umur tanaman 25 hst, dengan satuan gram, (5) kandungan $\mathrm{Pb}$ dalam daun selada, dilakukan dengan metode pengabuan basah dengan alat ukur AAS (Absorption Absorban Spektrophotometer) di Laboratorium Kesuburan Tanah, Fakultas Pertanian, Institut Pertanian Bogor.

\section{HASIL DAN PEMBAHASAN}

Hasil analisis ragam menunjukkan bahwa sumber air penyiraman dan frekuensi aplikasi insektisida tidak berpengaruh nyata terhadap tinggi tanaman, serta tidak terdapat interaksi antara kedua faktor tersebut. Hasil uji BNT (Tabel 2) menunjukkan bahwa respon tinggi tanaman dengan penyiraman air sumur tidak menunjukkan perbedaan dengan penyiraman air limbah rumah tangga. Demikian juga respon tanaman akibat penyemprotan menunjukkan tinggi yang sama walaupun dilakukan dengan berbagai frekuensi penyemprotan.

Tabel 2. Efek Sumber Air Penyiraman dan Frekuensi Aplikasi Insektisida terhadap Tinggi Tanaman Selada

\begin{tabular}{|c|c|c|c|c|c|}
\hline \multirow{3}{*}{$\begin{array}{l}\text { Sumber air penyiraman } \\
(\mathrm{K})\end{array}$} & \multicolumn{4}{|c|}{ Frekuensi penyemprotan insektisida (I) } & \multirow{3}{*}{$\begin{array}{c}\text { Rata- } \\
\text { rata }\end{array}$} \\
\hline & Tanpa & Satu kali & Dua kali & Tiga kali & \\
\hline & \multirow{2}{*}{\multicolumn{5}{|c|}{$\begin{array}{lll}19.18 & 16,69 & 18,22\end{array}$}} \\
\hline Air sumur & & & & & \\
\hline Air limbah rumah tangga & 18,39 & 16,63 & 15,98 & 16,64 & 16,92 \\
\hline Rata-rata & 17,86 & 17,91 & 16,31 & 17,44 & \\
\hline
\end{tabular}

Hasil analisis ragam menunjukkan bahwa jumlah daun tanaman selada tidak dipengaruhi oleh sumber air penyiraman dan frekuensi aplikasi insektisida, serta tidak terdapat interaksi antara kedua faktor tersebut. Dari hasil uji BNT (Tabel 3) terlihat bahwa respon jumlah daun tanaman selada pada umur 25 hst yang sama yaitu rata-rata 7 daun walaupun diberi aplikasi penyiraman air dengan sumber yang berbeda dan penyemprotan insektisida berbagai frekuensi.

Tabel 3. Efek Sumber Air Penyiraman dan Frekuensi Aplikasi Insektisida terhadap Jumlah Daun Tanaman Selada

\begin{tabular}{|c|c|c|c|c|c|}
\hline \multirow[b]{2}{*}{$\begin{array}{l}\text { Sumber air penyiraman } \\
(\mathrm{K})\end{array}$} & \multicolumn{4}{|c|}{ Frekuensi penyemprotan insektisida (I) } & \multirow{2}{*}{$\begin{array}{l}\text { Rata- } \\
\text { rata }\end{array}$} \\
\hline & Tanpa & $\begin{array}{l}\text { Satu kali } \\
\ldots \ldots \ldots \ldots \ldots . \ldots . \ldots\end{array}$ & $\begin{array}{c}\text { Dua kali } \\
\text {....buah... }\end{array}$ & Tiga kali & \\
\hline Air sumur & 6,63 & 7,73 & 6,97 & 7,10 & 7,02 \\
\hline Air limbah rumah tangga & 7,20 & 6,47 & 7,20 & 6,80 & 6,92 \\
\hline Rata-rata & 6,92 & 6,92 & 7,08 & 6,95 & \\
\hline
\end{tabular}


Hasil analisis ragam menunjukkan bahwa sumber air penyiraman dan frekuensi aplikasi insektisida tidak berpengaruh nyata terhadap berat basah tanaman, serta tidak terdapat interaksi antara kedua faktor tersebut. Demikian juga hasil analisis ragam untuk berat kering tanaman menunjukkan bahwa sumber air penyiraman dan frekuensi aplikasi insektisida tidak berpengaruh nyata terhadap berat kering tanaman, serta tidak terdapat interaksi antara kedua faktor tersebut. Hasil uji BNT berat berangkasan baik dalam kondisi basah (Tabel 4) maupun setelah dikeringkan dalam oven (Tabel 5) menunjukkan tidak terdapat perbedaan setelah diberi aplikasi penyiraman air dengan sumber yang berbeda dan penyemprotan insektisida berbagai frekuensi.

Tabel 4. Efek Sumber Air Penyiraman dan Frekuensi Aplikasi Insektisida terhadap Berat Basah Tanaman Selada

\begin{tabular}{|c|c|c|c|c|c|}
\hline \multirow{3}{*}{$\begin{array}{l}\text { Sumber air penyiraman } \\
(\mathrm{K})\end{array}$} & \multicolumn{4}{|c|}{ Frekuensi penyemprotan insektisida (I) } & \multirow{2}{*}{$\begin{array}{c}\text { Rata- } \\
\text { rata }\end{array}$} \\
\hline & Tanpa & Satu kali & Dua kali & Tiga kali & \\
\hline & \multicolumn{5}{|c|}{ (2) } \\
\hline Air sumur & 7,47 & 9,03 & 7,75 & 8,39 & 8,16 \\
\hline Air limbah rumah tangga & 8,61 & 7,77 & 8,16 & 7,45 & 7,99 \\
\hline Rata-rata & 6,92 & 8,40 & 7,96 & 7,92 & \\
\hline
\end{tabular}

Tabel 5. Efek Sumber Air Penyiraman dan Frekuensi Aplikasi Insektisida terhadap Berat Kering Tanaman Selada

\begin{tabular}{|c|c|c|c|c|c|}
\hline \multirow[b]{2}{*}{$\begin{array}{l}\text { Sumber air penyiraman } \\
(\mathrm{K})\end{array}$} & \multicolumn{4}{|c|}{ Frekuensi penyemprotan insektisida (I) } & \multirow{2}{*}{$\begin{array}{r}\text { Rata- } \\
\text { rata }\end{array}$} \\
\hline & Tanpa & Satu kali & $\begin{array}{c}\text { Dua kali } \\
\text {.........g.... }\end{array}$ & Tiga kali & \\
\hline Air sumur & 0,43 & 0,47 & 0,62 & 0,57 & 0,52 \\
\hline Air limbah rumah tangga & 0,58 & 0,45 & 0,47 & 0,50 & 0,50 \\
\hline Rata-rata & 0,50 & 0,45 & 0,54 & 0,53 & \\
\hline
\end{tabular}

Dengan demikian, secara umum dapat dikatakan bahwa perbedaan sumber air penyiraman tidak berpengaruh terhadap pertumbuhan tanaman selada yaitu tinggi tanaman, jumlah daun, berat basah berangkasan dan berat kering berangkasan. Kenyataan ini berarti kualitas air penyiraman tidak mempengaruhi pertumbuhan tanaman selada. Hal ini diduga perbedaan kualitas air tidak menciptakan kemampuan kondisi lingkungan yang berbeda dalam menunjang pertumbuhan dan hasil tanaman selada. Perbedaan kandungan bahan yang terlarut yang terdapat pada air sumur dan air selokan limbah rumah tangga diduga tidak menyebabkan perbedaan kesuburan media tanam, terutama dalam ketersediaan unsur hara bagi tanaman selada. Penggunaan air sumur maupun air selokan limbah rumah tangga untuk penyiraman cenderung hanya terkait pada menjamin ketersediaan air media tanam.

Frekuensi penyemprotan insektisida Calipso 240 SC juga tidak berpengaruh terhadap pertumbuhan tanaman selada baik dalam hal tinggi tanaman, jumlah daun, berat basah berangkasan maupun berat kering berangkasan. Hal ini menunjukkan penyemprotan insektisida Calipso 240 SC pada tanaman selada merupakan tindakan yang sia-sia bahkan cenderung bersifat pemborosan bila ditinjau secara ekonomi. Kenyataan di lapang juga menunjukkan bahwa tanaman selada lebih tahan terhadap hama dan penyakit tanaman dibandingkan dengan jenis tanaman sawi lainnya.

Hal menarik dalam penelitian adalah walaupun perbedaan sumber air penyiraman dan frekuensi aplikasi insektisida tidak berpengaruh terhadap pertumbuhan tanaman selada, namun hasil analisis ragam menunjukkan bahwa sumber air penyiraman dan frekuensi aplikasi insektisida berpengaruh nyata terhadap kandungan $\mathrm{Pb}$ dalam daun tanaman selada, serta terdapat interaksi antara kedua faktor tersebut.

Pada penelitian ini, respons kandungan $\mathrm{Pb}$ dalam daun tanaman selada akibat sumber air penyiraman menunjukkan pola yang sama pada berbagai taraf frekuensi penyemprotan insektisida yaitu kandungan $\mathrm{Pb}$ yang disiram dengan air selokan rumah tangga lebih tinggi daripada tanaman yang disiram dengan air sumur. Sedangkan pengaruh frekuensi penyemprotan insektisida pada taraf sumber air penyiraman menunjukkan bahwa kandungan $\mathrm{Pb}$ terjadi peningkatan yang signifikan akibat perbedaan aplikasi insektisida jika air penyiraman berasal dari sumur, tetapi untuk air penyiraman yang berasal dari selokan rumah tangga, peningkatan kandungan $\mathrm{Pb}$ baru terjadi setelah aplikasi dua kali. Kandungan $\mathrm{Pb}$ tertinggi terdapat pada tanaman yang disiram dengan air selokan limbah rumah tangga dan disemprot insektisida sebanyak 2 kali (Tabel 6).

Tabel 6. Efek Sumber Air Penyiraman dan Frekuensi Aplikasi Insektisida terhadap Kandungan Pb Dalam Daun Tanaman Selada

\begin{tabular}{|c|c|c|c|c|}
\hline \multirow{2}{*}{$\begin{array}{l}\text { Sumber air penyiraman } \\
(\mathrm{K})\end{array}$} & \multicolumn{4}{|c|}{ Frekuensi penyemprotan insektisida (I) } \\
\hline & Tanpa & Satu kali & Dua kali & Tiga kali \\
\hline & \multicolumn{4}{|c|}{ 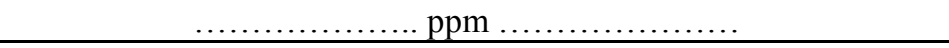 } \\
\hline \multirow[t]{2}{*}{ Air sumur } & $3,20 \mathrm{~A}$ & $4,20 \mathrm{~A}$ & $4,73 \mathrm{~A}$ & $7,17 \mathrm{~A}$ \\
\hline & a & $\mathrm{b}$ & $\mathrm{c}$ & $\mathrm{d}$ \\
\hline \multirow[t]{2}{*}{ Air limbah rumah tangga } & $5,57 \mathrm{~B}$ & $6,13 \mathrm{~B}$ & $7,97 \mathrm{~B}$ & $8,20 \mathrm{~B}$ \\
\hline & $\mathrm{a}$ & $\mathrm{a}$ & $\mathrm{b}$ & $\mathrm{b}$ \\
\hline
\end{tabular}

Keterangan : Angka yang diikuti huruf yang sama (huruf besar arah vertikal, huruf kecil arah horizontal) tidak berbeda nyata menurut uji BNT pada taraf $5 \%$. 
Dari hasil penelitian dapat dilaporkan adanya interaksi antara jenis sumber air penyiraman dan frekuensi penyemprotan insektisida Calipso 240 SC terhadap kandungan $\mathrm{Pb}$ pada daun selada. Kandungan $\mathrm{Pb}$ pada tanaman yang disiram dengan air selokan limbah rumah tangga lebih tinggi dari pada yang disiram dengan air sumur. Disamping itu terlihat bahwa semakin sering disemprot dengan insektisida Calipso 240 SC, kandungan $\mathrm{Pb}$ yang tertinggal pada daun tanaman selada semakin meningkat. Hal inilah yang diduga menyebabkan tanaman selada memiliki kadar $\mathrm{Pb}$ yang meningkat pada perlakuan aplikasi insektisida Calipso 240 SC dua kali dan disiram dengan selokan limbah rumah tangga.

Calipso 240 SC mempunyai bahan aktif thiacloprid $240 \mathrm{~g} / \mathrm{l}$ merupakan insektisida sistemik produk golongan Chloronicotinyl yang bekerja secara racun kontak dan lambung dan efektif untuk hama penghisap maupun lepidoptera. Penyemprotan insektisida memberikan sumbangan $\mathrm{Pb}$ kepada tanaman berupa residu dan phytotoxisitas disamping mempunyai pengaruh yang sangat luas terhadap hama, mortalitas serangga berguna, perubahan populasi hama, dan timbul hama sekunder (Wijn et al., 1993).

Timbal $(\mathrm{Pb})$ merupakan salah satu jenis bahan penyebab polusi utama logam berat (Salam et al., 1997). Media tanah merupakan salah satu sumber keberadaan logam berat di alam dan dapat berperan sebagai indikator kualitas lingkungan terutama dalam masalah pencemaran logam berat. Namun karena banyaknya faktor yang mempengaruhi kelarutan logam berat seperti $\mathrm{pH}$ dan kehadiran molekul-molekul pengkhelat di daerah perakaran tanaman dan kompleknya reaksi-reaksi yang terjadi dalam tanah, ternyata kandungan $\mathrm{Pb}$ dalam tanah bukan merupakan faktor utama yang mempengaruhi kandungan $\mathrm{Pb}$ dalam sayuran dan kandungan total $\mathrm{Pb}$ dan $\mathrm{Pb}$ terekstrak dalam tanah berkorelasi negatif dengan kandungan $\mathrm{Pb}$ pada sayuran. Dengan demikian faktor antropogenik dan lingkungan yang lebih mempengaruhi kandungan $\mathrm{Pb}$ dalam sayuran, sehingga kebiasaan petani menggunakan insektisida sebagai pencegahan hama sangat berbahaya karena dari hasil penelitian ternyata frekuensi penyemprotan insektisida mempengaruhi kandungan $\mathrm{Pb}$ dalam daun tanaman selada.

Kualitas air yang digunakan untuk pertumbuhan tanaman sangat menentukan kandungan logam berat dalam tanaman termasuk sayuran dan kandungan $\mathrm{Pb}$ pada tanaman selada yang disiram dengan air selokan limbah rumah tangga lebih besar dibandingkan dengan tanaman yang disiram dengan air sumur.

\section{KESIMPULAN}

Kesimpulan yang dapat diambil pada penelitian ini adalah:

1. Sumber air penyiraman tidak mempengaruhi pertumbuhan tanaman (tinggi tanaman, jumlah daun, berat basah berangkasan, dan berat kering berangkasan), tetapi berpengaruh terhadap kandungan $\mathrm{Pb}$ dalam daun tanaman selada.

2. Frekuensi penyemprotan insektisida juga tidak mempengaruhi pertumbuhan tanaman (tinggi tanaman, jumlah daun, berat basah berangkasan, dan berat kering berangkasan), tetapi berpengaruh terhadap kandungan $\mathrm{Pb}$ dalam daun tanaman selada.

3. Terdapat interaksi antara sumber air penyiraman dan frekuensi penyemprotan insektisida terhadap kandungan $\mathrm{Pb}$. Kandungan $\mathrm{Pb}$ tertinggi pada sumber air selokan limbah rumah tangga dan dua kali penyemprotan insektisida.

\section{DAFTAR PUSTAKA}

Alegria, A., R. Barbera, R. Boluda, F. Errecalde, R. Farre, dan M.J. Lagarda. 1991. Environmental cadmium, lead, and nickel contamination: possible relationship between soil and vegetable content. Bio. Chem., 339: 654-657.

Arisandi, P. 2002. Pengawasan sungguh-sungguh terhadap industri. http://www. terranet.or.id/masukandetil.php/ id=1293-28k, diakses 15 Agustus 2005.

Ecoton (Ecological Observation and Wetlands Conservation). 2004. Beberapa hal penting tentang timbal dan keracunan timbal. http://www.ecoton.or.id/ tulisanlengkap.php/id=1486, diakses 15 Agustus 2005.

Ellen, G., J.W. V. Loon, dan K. Tolsma. 1990. Heavy metal in vegetables grown in the Nederlands and in domestic and imported fruits. Food Res. Tech., 190: 34-39.

Handayani, E.P. 2002. Isolasi dan karakterisasi bakteri pereduksi merkuri asal Pongkor dan Kalimantan Tengah. J. Wacana Pertanian, I: 69-74.

Handayani, E.P. 2002. Identifikasi dan uji aktivitas bakteri pereduksi merkuri asal Pongkor dan Kalimantan Tengah. J. Wacana Pertanian, I: 60-64.

Handayani, E.P., Rakhmiati, Maryati. 2005. Kandungan Logam Berat Dalam Sayuran Akibat Pemberian Air dengan Kualitas Air Yang Berbeda. Laporan Hasil Penelitian Dosen Perguruan Tinggi Swasta SeKopertis Wilayah II.

Haryanto E., Suhartini T, dan Rahayu E. 2003. Sawi dan Selada. PT Penebar Swadaya. Jakarta. $117 \mathrm{hlm}$.

Herawati, N., I. F. Rivai, K. Koyama, dan S. Suzuki. 1998. Copper in rice and in soils according to soil type in Japan, Indonesia, and China: A baseline study. Bull. Environ. Contam. Toxicol., 60: 266-272.

Kartasapoetr, A.G. Hama Tanaman Pangan dan Perkebunan. 1993. Bumi Aksara. Jakarta.

Mangoendihardjo, S. 1982. Ilmu Hama. Raja Grafindo Persada. Jakarta.

McGrath, S.P., J.R. Sanders, dan M.H. Shalaby. 1988. The effect of soil organic matter levels on soil solution concentrations and extractabilities of manganese, zinc, and copper. Geoderma, 42: 177-188.

Moir, A.M dan L. Thornton. 1998. Lead and cadmium in urban allotment and garden soils and vegetables in the 
United Kingdom. Environ. Geochem. Res., 11: 113119.

Nasution, I., dan M. Al-Jabri. 2004. Status pencemaran logam berat di lahan sawah DAS Bengawan Solo. $J$. Wacana Pertanian, III: 81-90.

Noertjahyani dan P. Santoso. 2004. Kandungan N, P, dan $\mathrm{K}$ tanaman kedelai akibat aplikasi biostimulan dan cendawan arbuskula mikoriza pada pasir sisa dari pengolahan bijih. J. Wacana Pertanian, III: 28-34.

Rivai, I.F. 2000. Penentuan kandungan total $\mathrm{Cd}, \mathrm{Cu}$, dan $\mathrm{Zn}$ dalam tanah berdasarkan metode analisis, lokasi, dan jenis tanah di Indonesia. J. Tanah Tropik., VI: 1520.

Romieu, I., E. Palazuelos, M.H. Avila, C. Rios, I. Muñoz, C. Jimenes, dan G. Cahero. 1994. Sources of lead exposure in Mexico City. J. Nat. Ins. Environ. Health Sci., 102: 384-389.

Rukmana R. 2004. Bertanam Selada. Kanisius. Yogyakarta.

Salam, A.K. 1995a. Immobilisasi logam berat di dalam tanah selama 15 tahun. J. Ilmiah Ilmu-ilmu Pert., 3: 20-27.

Salam, A.K. 1995b. Pola hubungan ketersediaan unsur hara mikro kelompok logam berat dengan $\mathrm{pH}$ dan fosfor pada Ultisol Gunung Sugih Lampung Tengah. J. Pen. Pengb. Wil. Lahan Kering., 16: 1-11.
Salam, A.K., N. Sriyani, dan M. Hiradila. 1997. Kelarutan logam berat di daerah perakaran beberapa jenis gulma tropika yang tercemar timah hitam. J. Tanah Tropika, II: $117-122$.

Soepartini, M., S. Widati, M.E. Suryadi, dan T. Prihatini. 1996. Evaluasi kualitas dan sumbangan hara dan air pengairan di Jawa. Pemb. Pen. Tanah dan Pupuk., 14: 25-30.

Wijanto, S.E. 2005. Limbah B3 dan kesehatan. http://www.dinkesjatim.go.id/images/datainfo/ 200504121503-LIMBAH\%20B-3.pdf. diakses 16 Agustus 2005.

Wijn, M., P. Duives, R. Herbert, dan B. Brunekreef. 1993. Lead uptake from vegetables grown along highways. Inter. Arch. Occup. Environ. Helath., 52: 263-270.

Yeh, C.Y., H.Y. Chiou, R.Y. Chen, K.H.Yeh, W.L. Jeng, dan B.C. Han. 1996. Monitoring lead pollution near a storage battery recycling plant in Taiwan Republic of China. Arch. Environ. Contam. Toxicol., 30:227-234.

Zhu, Y. -G., S.-B. Chen, dan J. -C. Yang. 2004. Effects of soil amendments on lead uptake by two vegetable crops from a lead-contaminated soil from Anhui, China. Environ. Int., 30(3): 351-356.

Zulkifli dan Syarifuddin. 1995. Dampak kendaraan bermotor terhadap kandungan timah hitam tanah dan tanaman. Hlm. 545-553. Dalam L.I. Nasution et al. (eds.). Pros. Kongres Nasional VI HITI. Jakarta, 1215 Desember 1995. 